\section{Right Brain: \\ Past medical story}

Section Editor

Mitchell S.V. Elkind,

MD, MS

Dani Dumitriu, $\mathrm{PhD}$

Correspondence \& reprint requests to Dr. Dumitriu: dani.dumitriu@mssm.edu
L.M., a 71-year-old man presenting with gait disturbance, was my first Neurology patient upon entering the clinical clerkships. On my way to the Emergency Department, I learned from the chart that his past medical history (PMH) was significant for eastern equine encephalitis (EEE) 9 years earlier. I had never heard of EEE. In the elevator, I dutifully pulled out the tablet I carried in a fanny pack. To my amazement, I had to peruse several medical reference services before finding a short entry informing me that the often deadly eastern equine virus has a predilection for the basal ganglia.

I was still holding my tablet when I reached L.M., more interested in his rare previous disease than in his current difficulty walking.

"I understand you suffered from eastern equine encephalitis. Is this correct?" I asked, after introducing myself to a jolly obese gentleman appearing in no acute distress. L.M. affirmed the chart entry and provided details about sudden loss of consciousness, a 3 -week coma followed by months of paraplegia, and eventual complete recovery. On examination, L.M. had masked facies, a mixed tremor, cogwheel rigidity, intact strength and sensation, and shuffling gait. He reported all symptoms to have begun in the last month, with abrupt onset. His family history was positive for essential tremor and Alzheimer disease (AD) in his father.

The neurology resident presented L.M. the following day in morning report. EEE was brought up and I shyly raised my hand from the student section of the room.

"EEE has a predilection for the basal ganglia. Could the damage done to L.M.'s basal ganglia have slowly progressed to parkinsonism?" I asked.

"Postencephalitic parkinsonism," the attending mused thoughtfully. "Nine years is a long time, but that's an interesting thought. Why don't you look that up for us," he encouraged. Postencephalitic parkinsonism, I was soon reminded, was the subject of the movie Awakenings, which is about Oliver Sacks' 1960s discov- ery of 80 patients with this condition, resulting from the great sleeping sickness (aka encephalitis lethargica) that swept the world in the 1920s.

L.M. was clinically stable and in good spirits when I saw him the next morning, joking that I was too young to examine him.

"I don't know if I told you," he said as I was wrapping up, "I had eastern equine encephalitis 9 years ago."

After receiving permission from L.M., I talked extensively to his 2 daughters. L.M. lived alone in Florida, while his daughters lived in New York. When they'd last seen him 6 months prior, he was able to walk without assistance. However, they had noticed their father becoming increasingly forgetful in the past year. There were also mood and personality changes. $\mathrm{AD}$ was brought up. They relayed L.M.'s overwhelming fear of developing the disorder that claimed his own father.

In my literature review I found that the arthropod-borne eastern equine virus is an alphavirus from the togavirus family and contains singlestranded RNA. Only 270 US cases were documented by the Centers for Disease Control and Prevention between 1964 and 2010. About one-third of patients succumb to the infection. High fever, headache, confusion, and coma are universal, and most survivors are left with varying degrees of neurologic or behavioral sequelae. Imaging reveals lesions in the basal ganglia or thalamus in virtually all patients. ${ }^{1}$ Despite this, I did not find a single documented case of postencephalitic parkinsonism following EEE. Generally, the diagnosis of postencephalitic parkinsonism is restricted to the now-extinct encephalitis lethargica, whose causative agent remains unidentified. There are a handful of modern reports of postencephalitic parkinsonism following infection with viruses such as coxsackie, Japanese encephalitis B, and St. Louis viruses, ${ }^{2}$ though their validity is questioned by some experts. ${ }^{3}$ One study using serology for 17 arboviruses in postencephalitic vs idiopathic parkinsonism and 
controls found no evidence for a causal relationship between encephalitis and parkinsonism. ${ }^{4}$

The controversy cultivated my interest and after presenting my findings to the floor attending I was encouraged to write a case report. However, I first needed to get the records of L.M.'s EEE course. L.M. was delighted by the attention and immediately procured a huge pile of medical records. I studied each file, learning details of L.M.'s PMH that he himself had forgotten. Each encounter mentioned EEE yet lacked further detail. To my frustration, the records went back only 8 years.

The attending insisted that I not get discouraged and pointed out that EEE is a reportable disease, meaning that the Centers for Disease Control and Prevention or local Department of Health should have a record of the case.

A dozen phone calls later, expecting to be given yet another number, I was instead asked for L.M.'s date of birth. I heard typing in 1 ear and my heart pounding in the other.

"Here we go," the voice said. "Yes, he was reported as 'probable' EEE. Serum was sent to us, but he tested negative."

I was incredulous, but the record was unequivocal. I went to inform L.M. of my findings. Before I could begin, L.M. interrupted me excitedly.

"Look what I found!"

On his night table was a FedEx envelope with the records from his 2002 hospital stay. There was still hope I would find proof of a diagnosis of EEE! I pieced together a haphazardly arranged 54-page laboratory report. L.M.'s CSF was indeed tested for virtually all arboviruses, but all titers were "undetectable." Furthermore, the MRI report was not consistent with any of the viruses that cause postencephalitic parkinsonism. Generalized edema was noted, but there was no mention of basal ganglia involvement. My thorough investigation, rather than confirming the diagnosis of EEE, helped me realize that there was no evidence for the diagnosis in the first place.

Next, I moved on to the physician notes, attempting to understand the origin of the misdiagnosis. The admitting note stated that "the patient was diagnosed with viral encephalitis of unknown etiology." Two days later, the internist wrote "meningoencephalitis, probably viral in origin, though definite cause not found." On hospital day 5, the consulting oncologist documented: "Eastern equine virus serology is questionably positive." I was baffled. The only mention of laboratory studies was the 54-page opus I had just diligently organized and studied. I scoured both documents, searching for congruence, and realized the history contained a second error. The CSF protein level was listed as "187." However, the recorded lab- oratory value had been " 87. . It was around this time that serology was sent to the Florida Department of Health, but the file contained no record of this second negative result. On hospital day 20, another consulting physician wrote "viral encephalitis complicated by transverse myelitis and lower extremity paraplegia, subsequently reported positive for eastern equine encephalitis." The diagnosis of EEE-diligently reported during L.M.'s every medical encounter since-was nothing more than a case of the childhood-famous "telephone message game!"

I recounted my detective work to L.M. To my surprise, he was saddened by the news. I seemed to be draining him of prized memories. Why was postencephalitic parkinsonism an easier diagnosis for L.M. to accept than the subsequent "atypical AD, likely inherited?”

Truisms are not always born out of fact. They can be born out of conviction, faith, mistakes, and even malingering. When the Electronic Medical Record was popularized at the beginning of the century, "copy-and-paste" behavior was quickly recognized as a danger, with the propagation of "chart lore" a much dreaded consequence. ${ }^{5}$ On occasion, though, truisms are not attributable to frank mistakes, omissions, or the spread of false information by simple copying and pasting; rather they are born out of the essential need for narrative-the human desire to tell a story. There is something inherently more comforting in waking up paraplegic after a 3-week coma and recounting the story of surviving a specific and exotic-sounding virus than admitting to an ominous but foggy, un-named encephalitis.

I visited L.M. in the rehabilitation unit before his discharge.

"Do you think the eastern equine virus is what did this to me?" he asked me as we were saying goodbye, blissfully unaware of our last conversation.

My instinct was to remind him of my findings. I searched for the right words but instead thought of L.M.'s narrative. For 9 years now, he'd proudly told each doctor about the rare disease he'd beaten. For nearly a decade the special attention of inquisitive young doctors like me had given him comfort by validating his story. And then I thought of my own narrative: rewatching Awakenings, becoming wellinformed on a rare disease, solidifying my goal of becoming a physician-scientist. I thought of the bond that formed between an eager medical student and a parkinsonian patient who despite masked facies exuded a resilient ebullience.

"I don't know," I said. "Maybe."

\section{ACKNOWLEDGMENT}

The author thanks Drs. David Simpson, Michelle T. Fabian, and Barbara $\mathrm{K}$. Changizi for mentorship and editing of this manuscript. 


\section{DISCLOSURE}

The author reports no disclosures relevant to the manuscript. Go to Neurology.org for full disclosures.

\section{REFERENCES}

1. Deresiewicz RL, Thaler SJ, Hsu L, Zamani AA. Clinical and neuroradiographic manifestations of eastern equine encephalitis. N Engl J Med 1997;336:1867-1874.
2. Jang H, Boltz DA, Webster RG, Smeyne RJ. Viral parkinsonism. Biochim Biophys Acta 2009;1792:714-721.

3. Casals J, Elizan TS, Yahr MD. Postencephalitic parkinsonism: a review. J Neural Transm 1998;105:645-676.

4. Elizan TS, Schwartz J, Yahr MD, Casals J. Antibodies against arboviruses in postencephalitic and idiopathic Parkinson's disease. Arch Neurol 1978;35:257-260.

5. Hirschtick RE. A piece of my mind: copy-and-paste. JAMA 2006;295:2335-2336. 


\title{
Neurology
}

\author{
Right Brain: Past medical story \\ Dani Dumitriu
}

Neurology 2012;79;e98-e100

DOI 10.1212/WNL.0b013e31826aad4b

This information is current as of September 17, 2012

\section{Updated Information \& Services}

\section{References}

Subspecialty Collections

Permissions \& Licensing

Reprints including high resolution figures, can be found at: http://n.neurology.org/content/79/12/e98.full

This article cites 5 articles, 0 of which you can access for free at: http://n.neurology.org/content/79/12/e98.full\#ref-list-1

This article, along with others on similar topics, appears in the following collection(s):

Alzheimer's disease

http://n.neurology.org/cgi/collection/alzheimers_disease Clinical neurology history

http://n.neurology.org/cgi/collection/clinical_neurology_history Error in medicine http://n.neurology.org/cgi/collection/error_in_medicine Gait disorders/ataxia http://n.neurology.org/cgi/collection/gait_disorders_ataxia

Information about reproducing this article in parts (figures,tables) or in its entirety can be found online at:

http://www.neurology.org/about/about_the_journal\#permissions

Information about ordering reprints can be found online: http://n.neurology.org/subscribers/advertise

Neurology ${ }^{\circledR}$ is the official journal of the American Academy of Neurology. Published continuously since 1951, it is now a weekly with 48 issues per year. Copyright Copyright (? 2012 by AAN Enterprises, Inc.. All rights reserved. Print ISSN: 0028-3878. Online ISSN: 1526-632X.

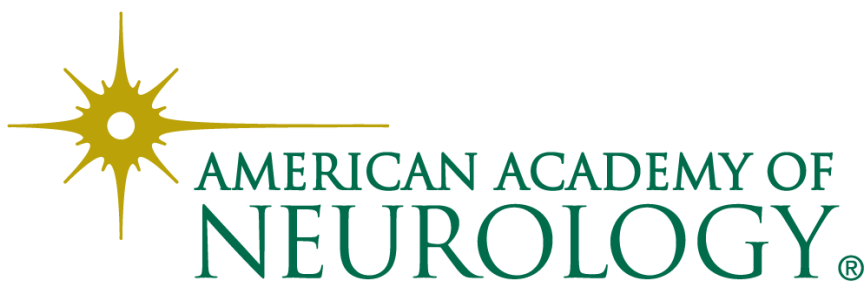

